ESTUDOS RBE?

\title{
Entendendo raça e racismo: por uma educação racialmente crítica e antirracista* $^{*}$
}

Ronald D. Glass

\begin{abstract}
Resumo
Discute premissas subjacentes a perspectivas sobre raça e permite uma abordagem mais estratégica para transformar o racismo. Define cinco posições - supremacia racial, cegueira racial, sensibilidade racial, crítica racial e antirracista - que sugerem um caminho de desenvolvimento moral e político que pode guiar o trabalho nas escolas e na sociedade para superar o racismo. O objetivo da análise não é atribuir culpa ao passado ou ao presente; ao contrário, é fornecer uma estrutura para apoiar a responsabilidade e a prestação de contas individual e coletiva que pode levar à implementação de um grau maior de justiça. A educação racialmente crítica e antirracista une as pessoas à história de lutas por justiça e une umas às outras para as próximas lutas, criando assim o sonho de uma democracia justa mais perto de se tornar realidade.
\end{abstract}

Palavras-chave: raça; racismo; educação antirracista.

* Agradeço a Sandra Regina Sales pela leitura atenta do texto e a Celina Frade pela tradução. 


\section{Abstract \\ Understanding race and racism: toward a race-critical anti-racism education}

This essay uncovers assumptions underlying perspectives on race and enables a more strategic approach to transforming racism. It defines five positions - race-supremacy, race-blindness, racesensitivity, race-critical, and anti-racism - that suggest a pathway of moral and political development that can guide work in schools and society to overcome racism. The goal of the analysis is not to assign blame for either the past or the present; rather, the aim is to provide a framework to support individual and collective responsibility and accountability that can lead to the achievement of a greater measure of justice. Race-critical anti-racism education links people to the history of struggles for justice, and links them to one another for the struggles ahead, thus bringing the dream of a just democracy closer to realization.

Keywords: race; racism; anti-racism education.

\section{Introdução}

Entre os mais importantes desafios éticos e políticos colocados para os educadores na atualidade estão as questões de raça e racismo. Uma das maiores dificuldades é que muitas vezes os debates acalorados que geralmente se travam sobre essas questões, ao invés de clarificar, obscurecem o que realmente está acontecendo e o que precisa ser feito para enfrentá-las. Este artigo apresenta um marco conceitual que expõe presunções e ressalta perspectivas teóricas e políticas sobre raça, possibilitando uma aproximação mais estratégica para combater o racismo em nossas escolas e sociedades. Nesse sentido, define cinco posições - supremacia racial, cegueira racial, sensibilidade racial, crítica racial e antirracista - que sugerem um caminho de desenvolvimento moral e político que está aberto para todos aqueles que se preocupam seriamente com a superação da histórica divisão racial que marca e mina as escolas e a nação americana. O objetivo não é atribuir culpa ao passado ou ao presente, a meta é estimular a responsabilidade individual e coletiva para alcançar maiores possibilidades de justiça social.

Enquanto a raça pode ser quase uma obsessão para muitos nessa sociedade (Terkel, 1992), poucos sabem o que fazer sobre isso. Os estadunidenses permanecem profundamente divididos em suas percepções 
${ }^{1}$ Grande marcha pelos direitos civis, de Selma à Montgomery, liderada por Martin Luther King Jr. sobre relações raciais e os afro-americanos, em particular, são pessimistas com respeito a perspectivas de melhoras (Gallup Poll, 2004). Uma resposta adequada à questão racial requer uma transformação radical em cada um de nós, em nosso entendimento sobre nós mesmos. James Baldwin (1998, p. 8; grifos no original) estava certo: "Se eu não sou o que me falaram que eu sou, então isso significa que você não é o que você também pensou que era"! Do mesmo modo, é preciso realizar difíceis transformações estruturais para que o sonho de comunidades e escolas justas e democráticas seja possível.

As reflexões presentes neste trabalho emergem de uma práxis que se funda na filosofia da Educação Libertadora (Glass, 2001), forjada em décadas de participação nos movimentos sociais. Posso afirmar que minha consciência sobre raça e racismo começou a tornar-se crítica na década de 1960, quando o movimento dos direitos civis ganhou força nos Estados Unidos. Racismo e antissemitismo sempre estiveram presentes em minha vida numa pequena cidade de Ohio, onde minha família foi a primeira família judia a viver em uma região da cidade com escolas de muito prestígio. Essa experiência, com suas vantagens e desvantagens, marcou-me profundamente, pois as contradições da posição social da minha família refletiam a posição dos judeus dentro da ordem racial local (Biale, Galchinsky, Heschel, 1998). Aquela comunidade presumia que meus pais, a despeito de um exame mais aprofundado sobre suas relações com um casal afro-americano que trabalhava em nossa casa e no consultório médico de meu pai, eram aliados da comunidade negra. Assim, reconhecidos publicamente como aliados da causa negra, meus pais levaram-me à minha primeira manifestação do movimento dos direitos civis - era a marcha em solidariedade em Selma. ${ }^{1}$ No ensino médio, eu ainda não tinha incorporado consistentemente os princípios da justiça social e do antissemitismo, mas eu sempre falava sobre os problemas raciais, às vezes desafiando o técnico de basquetebol em meio aos seus discursos quando ele usava palavras com sentido racista tentando motivar o time no intervalo de um jogo do campeonato escolar. Meu ativismo aumentou durante o período universitário, embora o foco tenha mudado da justiça social para os protestos contra a guerra. Ainda que eu não fosse um dos líderes do movimento, eu senti profundamente aquele momento histórico e questionei certezas que eu tinha como absolutas. Escolhi trabalhar no campo da Educação acreditando ser esta um instrumento estratégico para que o futuro pudesse ser influenciado em um sentido de mudanças radicais na sociedade.

Com a publicação do livro Pedagogia do oprimido e da Revista Educacional de Harvard (Freire, 1970 a, b, c), as ideias de Paulo Freire levaram-me a perceber com maior clareza como a educação pode trabalhar a serviço da mudança social. Comecei a fazer a minha parte como professor de uma "Escola livre" e consultor de uma agência de serviços familiares, onde comecei a propor pequenos projetos que previam intervenções estratégicas. Nesse período, voltei à universidade para estudar Filosofia da Educação na pós-graduação. Tomando a sério um dos ensinamentos 
de Marx, quando afirma que a filosofia não é apenas para entender, mas para mudar o mundo, dediquei um longo tempo da minha vida ao esforço de ajudar a construir um movimento nacional que articulasse a luta antimilitarista e antirracista. Desenvolvi um projeto de educação de jovens e adultos que trabalhava com um conjunto de movimentos e organizações de base. Tive a sorte de ter Freire e Myles Horton (1990) como colaboradores em alguns desses esforços.

Depois de uma década desenvolvendo esse trabalho, tive a oportunidade de completar meu doutoramento e coordenar o Departamento de Filosofia da Universidade Stanford, especializado em culturas, ideias e valores - um programa que ganhou notoriedade devido aos ataques de setores da direita acadêmica e política, por ser um programa politicamente correto (D'Souza, 1991). A possibilidade de refletir criticamente sobre minha experiência prévia, aliada ao aprofundamento, proporcionou-me valiosas contribuições, que, por sua vez, ajudaram a dar forma a outros projetos voltados para transformações estruturais nas escolas urbanas. ${ }^{2}$ Em meu atual trabalho como professor universitário, no qual atuo prioritariamente com alunos provenientes das classes trabalhadoras, continuo envolvido com projetos de extensão para a comunidade pobre e com formação continuada de professores (prioritariamente brancos) sobre os desafios colocados pelas ideologias de raça e classe social.

Este artigo elabora um dos aportes teóricos que desenvolvi nesses lugares para facilitar a consciência e a ação críticas necessárias para transformar as condições limitantes da raça e do racismo:

- Supremacia racial: A raça diz tudo.

- Cegueira racial: A raça não diz nada.

- Sensibilidade racial: Raça diz coisas positivas.

- Crítica racial: Raça é uma coisa que nós fazemos e algo que é feito a nós. É cultural e historicamente construída e diz coisas contraditórias.

- Antirracismo: Raça fala sobre e é uma consequência do racismo. Superar o racismo significa, em parte, transcender a raça.

Às vezes as pessoas imaginam que, por causa da minha longa experiência de trabalho sobre os problemas raciais e justiça social, eu sou livre de contradições, seja em pensamento, sentimentos ou ações. Entretanto, pensar dessa maneira é um equívoco. Não é possível escapar completamente de ser racista, vivendo em uma sociedade que ainda se estrutura fortemente pelo racismo. Eu me mantenho marcado pelos privilégios de minha pele branca, bem como pelos privilégios criados pela minha classe social e pelo meu gênero. Mesmo que nós mudemos fundamentalmente a cultura e as instituições dentro das quais vivemos, continuaremos a habitar e a sermos habitados pelas ideologias dominantes. A profundidade e a amplitude da ideologia racista e seu implacável alcance no mais íntimo domínio de nossas vidas são revelados em um comentário feito pouco tempo atrás pelo filho Ben, que tinha então seis
${ }^{2}$ Nos Estados Unidos, "urban schooling" são escolas localizadas no centro das cidades e são frequentadas pelas classes populares. 
anos. Ben é mestiço, mas a maioria das pessoas o considera negro por causa da cor da sua pele, de suas características faciais e de seu tipo de cabelo. Em um final de tarde, eu relatava que uma família amiga de Gana, Les, recebera a cidadania estadunidense naquele dia. Ben olhou-me perplexo: "Cidadania?" "Estadunidense, Les se tornou oficialmente um estadunidense," eu respondi. Ben parecia mais perplexo, meio agitado e então exclamou: "Você quer dizer que Les ficou branco?!" A ideologia dominante - ser estadunidense é ser branco - vinha habitando Ben, embora ele viva em uma família que implacavelmente critica o racismo e as injustiças sociais, que convive com uma grande diversidade de amigos e se dedica diariamente à luta pela transformação da sociedade.

Assim sendo, o objetivo desta análise e as ações que elas possam engendrar não têm o sentido de nos tornar mais puros e moralmente justos ou livres de atitudes, crenças ou comportamentos culpáveis, mas apenas contribuir para que nos engajemos mais profundamente nas lutas internas e externas, necessárias para a superação do racismo e para que possamos viver juntos em uma sociedade respeitosa. A práxis que propõe não busca a perfeição, e sim alargar nosso horizonte com relação à nossa compreensão e ação críticas. Em síntese, este trabalho é "uma espécie de psicanálise histórico-cultural e política" (Freire, 1994, p. 55) que articula transformações pessoais, institucionais e sociais, que possam encarnar mais completamente nossos sonhos de justiça.

\section{Supremacia racial e igualdade humana}

Os documentos fundadores dos Estados Unidos (EUA) expressam uma compreensão contraditória sobre raça. Por um lado, a garantia de direitos humanos universais e inalienáveis implica igualdade, e este princípio tem sido fundamental na luta para a superação das injustiças raciais. Por outro lado, o status moral da igualdade e os direitos humanos básicos foram colocados em questão no que se refere aos negros (livres ou escravizados), aos indígenas e às mulheres. A supremacia racial tornou-se uma ideia que estruturou as leis e as instituições dos EUA, exatamente como se evidenciou na vida cotidiana, onde o racismo apareceu "não como uma anomalia da democracia estadunidense, mas fundamental para ela" (Jacobson, 1998, p. 12). Sendo assim, aqueles que lutam contra as desigualdades raciais devem se confrontar com uma longa história de práticas de supremacia racial que se articula a poderosos mecanismos que as explicam e justificam e que, por sua vez, se mantêm vivos dentro da cultura do país. A supremacia racial que a maioria das pessoas aceita como paradigma sobre o racismo afirma a superioridade de uma raça fundada em algumas características de pessoas que ocorrem naturalmente e que não são sujeitas a mudanças. Isso sustenta que a raça diz tudo o que é mais importante sobre uma pessoa e define suas capacidades intelectuais e morais, indicando até suas inclinações de trabalho, atléticas ou sexuais. 
Ilustres homens de estado, pensadores e teólogos têm legitimado a supremacia racial e, embora essa lógica tenha mudado ao longo dos anos, no nascimento dos EUA ela se originou de interpretações bíblicas. A hierarquia estabelecida divinamente, e aparentemente revelada na King James Bible, pressupõe uma ordem racial. Depois de Darwin, a ordem racial pré-estabelecida passou a ser vista como uma consequência natural da seleção e da sobrevivência de acordo com a capacidade de adaptação. As imutáveis leis de Deus e da ciência similarmente estabeleceram a supremacia da raça branca. Ambas as visões continuam a atrair adeptos e mais recentes intérpretes e também a informar explicações sobre diferenças entre pessoas (Wellman, 1993); cada raça é classificada em um ranking de acordo com as verdades imparciais da genética, com justos testes de inteligência ou ainda de acordo com os divinos poderes das análises estatísticas sobre a vida social. Os argumentos da supremacia racial nunca mencionam que brancos tiveram vantagens educacionais, sociais, políticas e econômicas que lhes garantiram os recursos e os privilégios que são tomados como justos resultados de esforços individuais. Assim, o debate continua a ignorar os mecanismos que causam a curva dos sinos que parece traçar as diferenças raciais até os dias de hoje (Frazer, 1995), enquanto os efeitos da supremacia racial silenciosamente matam esperanças e sonhos de muitas jovens nações.

As práticas sociais associadas à ideia de supremacia racial têm mudado consideravelmente, mas não desapareceram. Na atualidade, provavelmente, uma maioria considerável de pessoas duvida da validade da noção de supremacia racial e dos rankings que declarados ideólogos raciais produziram. Ainda existem desigualdades raciais na renda, na educação e nas oportunidades de emprego (Carnoy, 1994) e são exatamente as pessoas de $\operatorname{cor}^{3}$ que continuam a sofrer humilhações diárias e a lutar contra atitudes racistas encontradas em cada recanto da nossa cultura, incluindo a cultura escolar e universitária. Traços da supremacia racial podem ser percebidos em disparidades de financiamento (Kozol, 1991), separação das turmas por habilidades (Oakes, 1985) e no preconceito inconsciente de professores (Dornbusch, 1994), que continuam discretamente a fomentar o fracasso dos menos favorecidos frente aos testes padronizados (Orfield, Kornhaber, 2001). Esses efeitos impregnam escolas e desafiam até os professores mais criativos (Yeo, 1997), que se veem identificados como "atores brancos" entre muitos alunos de cor (Fordham, 1996). Além disso, a educação bilíngue e as políticas de ação afirmativa estão crescentemente desacreditadas e sofrendo ataques como se o legado da supremacia racial as tenha fadado ao passado (Macedo, 2000; Moses, 2002).

Educadores engajados com a igualdade humana não podem perder de vista a face manchada de sangue da história e os rostos aflitos dos alunos de cor presentes nas escolas de hoje, que se esforçam para garantir seus direitos e oportunidades justas. A supremacia racial não deve ter lugar em instituições educacionais ou em qualquer outro espaço cívico ou cultural, mas superá-la não será fácil. O racismo é uma formação ideológica que se
3 "Pessoas de cor" é uma expressão delicada, imprecisa e se refere a uma grande variedade de grupos, mas parece a melhor alternativa disponível para se referir às pessoas não brancas. 
instala dentro de uma estrutura de privilégios e poderes e se manifesta por toda a complexa rede de culturas que constitui a nação. Ele se revela por meio de atitudes individuais, sentimentos e crenças, práticas institucionais discriminatórias, ideias e símbolos e, ainda, por uma extensa variedade de atos presentes no cotidiano. O racismo está inserido dentro de significados culturais e linguísticos, bem como nas relações sociais que geram sistematicamente desvantagens para as pessoas de cor (Wetherell, Potter, 1992). Se, por um lado, é verdade que uma "inflação conceitual" pode obscurecer o racismo por relacioná-lo a muitas questões (Miles, 1989), por outro lado, é importante não reduzi-lo a apenas as manifestações violentas feitas pela Ku-Klux-Klan. Embora seja difícil discernir o que deveria contar como exemplo de racismo, e diferentes exemplos merecem diferentes níveis de opróbrio moral (Blum, 1999), educadores e cidadãos conscientes não devem ter muita cautela no esforço de desvelar as manifestações da ideologia racista na vida cotidiana. Afinal de contas, a mais consistente teologia, a ciência mais exata e os mais fortes valores concordam em rejeitar profundamente a noção de raça suprema. Consequentemente, quanto mais as práticas racistas se transformarem em objetos de um diálogo crítico por toda a sociedade, mais claramente as pessoas serão capazes de distinguir suas verdadeiras manifestações e significados.

A supremacia racial e o racismo não podem ser totalmente superados por que cada pessoa que cresce dentro dessa cultura torna-se, de alguma maneira, por ela contaminada. Assim, tal cultura deve ser questionada em todos os espaços, dos mais íntimos aos mais públicos. Embora as pessoas brancas se beneficiem dos privilégios da cor da pele, apesar de suas atitudes e práticas individuais, pois os benefícios derivam de uma rede muito poderosa de relações sociais e institucionais, o exame crítico desses privilégios pode gerar novos comportamentos e engajamentos para lutar contra o racismo (Delgado, Stefancinc, 1997; Tatum, 1994). Os privilégios baseados na cor das peles mais claras similarmente outorgam benefícios para pessoas de cor (ambas dentro de seus grupos e dentro de sociedades dominadas por brancos) independentemente de atitudes e sentimentos pessoais ante a esses privilégios (Early, 1993). Consequentemente, esforços para conter esses privilégios, como durante o "Negro é bonito" na era dos Direitos Civis, podem produzir ganhos substantivos. Embora existam importantes diferenças na forma como as raças são situadas na e pela ordem social, cada pessoa é inevitavelmente tocada pelo racismo e implicada com a supremacia da raça branca, até mesmo as pessoas que claramente resistem a todas as formas de racismo, bem como ao supracismo branco. Pessoas de todas as raças podem ser muito preconceituosas, expressar uma repugnância moral à ideologia racial e formar instituições que discriminam injustamente aqueles que são racialmente diferentes, mas nessa sociedade apenas os brancos se beneficiam por terem essas práticas individuais e coletivas apoiadas por históricas forças que definem as normas institucionais e sociais. Essas diferentes posições ante a ordem racial requerem diferentes e particulares tarefas libertadoras. 
Outras sociedades - como na África, Ásia, entre outras - são racistas e fundadas com base na ideologia da supremacia racial, mas não colocam os brancos no topo do poder. Em cada caso, os poderes social, econômico e político são dominados por um grupo. A discriminação institucional e os preconceitos pessoais são tomados como a maneira normal de ser nessa cultura. Uma análise do racismo que desvende a sustentação ideológica baseada no poder tem várias consequências, uma das quais é que o racismo pode sobreviver em um contexto em que poucas pessoas explicitamente ou conscientemente sustentem visões de supremacia racial. Este é o caso atual das escolas públicas nos EUA. A despeito do fato de que as escolas ocupam um lugar reconhecidamente importante nos esforços para corroer o racismo e um número significante de professores buscam conscientemente maneiras de tratar os alunos com cuidado e respeito sem tomar em conta a raça, os processos instrutivos e avaliativos das escolas, que são centrais para as legitimações da ordem racial atualmente existente, mascaram a distribuição de vantagens e desvantagens prévias e que afetam os resultados dessas competições que são supostamente neutras. As iniquidades nos resultados das operações do sistema escolar perturbam muitos professores e a outros defensores das igualdades de oportunidades. Esses defensores do tratamento justo rejeitam o sistema da supremacia racial do passado e procuram desestruturar a sua herança. Eles estão certos de que a raça não fala tudo sobre as pessoas e de tal maneira resistem a essas declarações de cumplicidades com o racismo, buscando reafirmar-se por meio de identificações com posições e posturas e programas que buscam a equidade e a diversidade.

\section{Cegueira racial $^{4}$}

Como contraponto à ideologia da supremacia racial, pela qual a raça diz tudo, a posição da cegueira racial aposta na premissa de que a raça não diz nada moralmente, intelectualmente ou socialmente importante sobre uma pessoa. Isto é, o respeito pelos outros implica ignorar totalmente a raça, já que ela não é significativa na proporção de seu caráter, na construção de suas habilidades e talentos ou na sua capacidade de fazer contribuições sociais valiosas (Steele, 1990). Segundo essa visão, para chamar atenção, ou para levar em consideração, a raça de uma pessoa consiste exatamente em negar a ela a sua individualidade e em sucumbir a pressuposições com base apenas numa participação atribuída a um grupo. Esses pressupostos constituem as bases da própria supremacia racial. Os defensores da cegueira racial também ressaltam que as instituições políticas e jurídicas americanas têm como base os direitos individuais e não de grupos.

A visão tradicional da cegueira racial do liberalismo existe desde os primórdios da nação, mas, em anos recentes, ela se tornou moda nos círculos conservadores que mudam os argumentos em seu próprio benefício tentando acabar com a ação afirmativa. Eles condenam o uso
${ }^{4}$ A expressão "cegueira racial" ao invés de "cegueira à cor" é usada para lembrar que a questão central é a raça, não a cor. 
${ }^{5}$ Glass (2000a) discute esta ideia em relação a um espectro mais amplo de ordens ideológicas. governamental da identidade racial nas políticas, operações e alocações de recursos, mesmo que seja para reparar a discriminação histórica. O argumento é de que a justiça e a igualdade regem a cegueira racial e as instituições públicas, em especial, não deveriam levar a raça em consideração, já que toda essa consideração é suspeita. Os sucessivos ataques à ação afirmativa na Califórnia, Texas e em outros lugares evidenciam o crescente poder político de certas formas dessa visão, apesar das maneiras de argumentar que geralmente escondem os esforços de corroborar e assegurar o privilégio racial branco. A defesa da ação afirmativa deve reconhecer o mérito de certas interpretações da cegueira racial como meta de uma sociedade democrática justa e, também, justificar procedimentos de consciência racial para se chegar a ela (Appiah, Gutmann, 1996). Essa defesa é bastante sólida, mesmo envolvida em dificuldades políticas e filosóficas; porém, antes de seguir essa linha, precisamos de mais explicações para a cegueira racial sem a sua mancha de cinismo.

Um dos pressupostos da cegueira racial é a declaração de intenção de reter julgamento sobre uma pessoa ou um grupo com base em supostas identificações raciais. Ninguém é atualmente capaz de "não ver" as características fenotípicas e morfológicas de pessoas que são os símbolos culturalmente definidos de raça, mesmo se sua visão de cor for fisiologicamente prejudicada devido à estrutura de sua retina. Mas é possível, com muita prática e atenção rigorosa aos funcionamentos da ideologia dominante, habituarmo-nos a resistir aos estereótipos e tentarmos engajar pessoas como indivíduos. Isso não é fácil, porque só o fato de crescermos nessa sociedade nos insere inexoravelmente dentro da ordem racial - onde ser americano é ser branco -, de forma a moldar profundamente práticas, atitudes, sentimentos e crenças cotidianas. Ideologias estão inesperadamente presentes em nós mais do que estamos nelas presentes mediante escolhas ou atividades conscientes. As perspectivas com tintas ideológicas da ordem racial são raramente adquiridas por meio do ensino e da aprendizagem explícitos. Portanto, ser racialmente cego de fato implica uma resistência ininterrupta às percepções e ações do senso comum, sendo que as pessoas (independentemente de sua posição dentro da ordem racial) não conseguem alcançar isto consistentemente sem intervenções intencionais para moldar uma conscientização crítica.

Para demonstrar como as ordens ideológicas estão presentes nas pessoas, consideremos como as "regras" de como tomar o elevador "ganham" usuários. ${ }^{5}$ Nos centros urbanos, todos conhecem virtualmente o modo adequado de se tomar um elevador. Após refletirem com cuidado, as pessoas descrevem e concordam prontamente com as regras básicas de como tomar um elevador. Qualquer um sabe que: você localiza saídas específicas em prédios de vários andares adjacentes nos botões direcionais para cima e para baixo; você aperta o botão desejado; quando as portas se abrem, você entra e aperta outro botão indicando seu destino (você pode pedir a outro passageiro para fazer isso se não puder alcançar o botão sem incomodar os outros); você caminha para a parte de trás o mais afastado possível dos outros passageiros e olha para as portas (em 
elevadores de vidros é permitido, embora não obrigatório, olhar para as paredes transparentes); você pode olhar para os números iluminados do destino acima ou do lado das portas, mas deve evitar mais do que um rápido contato visual com os outros; você deve diminuir a conversa, abaixar a voz e restringir os comentários a amenidades, notícias leves, esportes, etc. Mais regras podem ser adicionadas a essa lista ou variantes podem ser aplicadas em contextos locais específicos (como quando os passageiros tomam o mesmo elevador juntos diariamente). A questão aqui é que as regras são universalmente conhecidas entre aqueles que tomam elevadores, mesmo que raramente ensinadas, como quando uma criança é reprovada se quebrar uma regra (mesmo sendo uma regra que diz que as crianças podem quebrar as regras). Nenhuma escolha consciente é exigida para as práticas culturais (regras implícitas) de se tomar um elevador para ganhar usuários culturalmente competentes; uma pessoa precisa apenas tomar o elevador. Da mesma forma, a ordem racial ganha "usuários" culturalmente competentes que conhecem as regras de relações raciais e o significado de identidades raciais sem escolhas conscientes.

Pesquisas mostram que crianças de dois anos já entendem a ordem racial e sentem implicitamente quais grupos são favorecidos (Aboud, Doyle, 1993; Derman-Sparks, Higa, Sparks, 1980; Katz, 1982; Phinney, Rotherman, 1987). O posicionamento subordinado de ordem racial das crianças de cor pode lhes ser especialmente danoso e, mais ainda, quando o fracasso escolar se torna normativo para elas (Mcdermott, 1974) e quando os adultos na escola não interferem para conter esses efeitos (Comer, 1989). As crianças notam diferenças na cor da pele, nas características faciais, no comprimento, estilo e textura do cabelo, na linguagem e na fonética. Elas conseguem também classificar as pessoas em termos de raça e hierarquia de classe de forma confiável, lendo símbolos culturais complexos (como roupas, sapatos, carros ou vizinhanças), papéis e relações sociais (como as reveladas em padrões de conversação ou interação física) e relações de poder (Ramsey, 1995; Troyna, Hatcher, 1992).

As regras e hierarquias de ordens ideológicas não são transmitidas por meio da geografia física e social da vida das crianças. Como as escolas e bairros permanecem substancialmente segregados, os brancos de classe média e alta quase não têm conhecimento direto pessoal da diversidade entre as pessoas de cor (Frankenberg, 1993) e, portanto, imagens propagadas em massa pela mídia e estereótipos da ideologia dominante moldam percepções diante de poucos contraexemplos. Os horizontes brancos da ordem racial podem também confinar as pessoas de cor ou de descendência racial mista (Early, 1993). Crescer em ambientes monocromáticos leva quase todos os alunos brancos nos meus cursos, quando perguntados como sabem sobre raça, a "testemunharem a branquidade" (Fine, 1997) pela primeira vez: eles asseguram que "a raça nunca foi um problema", restando a eles um "nada" a dizer. Outras perguntas revelam que isso geralmente significa que eles nunca foram pessoalmente engajados num conflito racial óbvio, como se esses conflitos fossem a única 
${ }^{6}$ Alvin Poussaint, psiquiatra de Havard, identificou este processo num curso que participei em 1971. coisa importante sobre a raça. Eles são negligentes sobre o quanto todo o tecido de suas vidas é traçado de acordo com a ordem racial e, por sua vez, o quanto o que fazem, percebem, pensam e sentem é uma "questão racial". Eles se surpreendem com o fato de que o privilégio racial possibilita a raça a não "ser um problema" para alguém e que esse tipo de cegueira racial é uma característica do fato de ser branco (Fine, Weis, Powell, Wogn, 1997).

As relações interpessoais, tanto quanto a macrogeografia física e social, facilitam o ganho inconsciente de pessoas pela ordem racial. Microagressões costuradas em todo o tecido social são realizadas inconscientemente pelos brancos e asseguram privilégios no nível micro-racial. ${ }^{6}$ Consideremos os seguintes exemplos: andando numa calçada ou numa passarela de um shopping center, uma mãe branca e sua filha pequena (ou um pai branco e seu filho pequeno) se aproximam de um homem negro caminhando em direção a elas vindo da direção oposta. Ao pegar a mão da filha, a mãe se desvia ligeiramente da trajetória de interseção; ao pegar a mão do filho, o pai continua sua trajetória original e força o homem negro a abrir caminho. Em ambos os casos, os filhos são segurados inconscientemente pela aparente ameaça e necessidade de cuidado, além do filho também gostar da confiança demonstrada pelo domínio do pai sobre o espaço social. O homem negro registra a cautela e a afirmação do privilégio, sentindo então o peso de absorver outro pequeno assalto a sua dignidade. Da mesma forma, uma rede consistente de interações silenciosas nas escolas insere as crianças numa ordem racial (e outras ordens também), por exemplo, o status racial se torna claro por meio dos padrões de observação e punição dos professores, ao passo que as crianças entendem suas posições com uma clareza desenvolvida pelos instintos de sobrevivência; assim, se mediada ou ao vivo, a ordem racial ganha substância e conforto. Isso explica porque que todos que cresceram nos Estados Unidos conhecem as regras para conduzir a ordem racial, caso gostem ou não ou tenham pensado sobre ela ou não.

Essas considerações nos forçam a olhar com ceticismo para as alegações da cegueira racial porque, na medida do possível, ela deve ser um repúdio determinado da realidade de senso comum da cultura dominante unida a um comprometimento firme com um entendimento crítico de como a ordem racial nos rodeia e nos impregna. Mas raramente este tipo de resistência comprometida a julgamentos com tintas ideológicas é visível; geralmente, a cegueira racial deixa sem perguntas a injusta ordem racial existente e, portanto, ainda apresenta privilégios guardados por uma cultura nascida e ainda não amamentada pela supremacia racial. Da mesma forma, os traços da supremacia racial são revelados pela presunção de que é mal educado ou ruim "perceber" a raça. Assim como os ativistas dos direitos dos deficientes ficam envergonhados com outras deficiências físicas, muitos pais brancos silenciam seus filhos que, curiosamente, expressam seu problema, surpresa ou espanto em relação àqueles racialmente diferentes deles. O silêncio confina a ordem racial ao reino do silêncio, onde ele se apodera das crianças com hábitos 
mentais e de ação difíceis de alcançar mesmo com uma conscientização crítica. Os segredos confidenciam dentro da memória que "não é bom" comentar (ver) a deficiência racial porque ela supostamente aponta para vantagens sociais e indica uma vida sofrida de tristeza e inveja. Isto é, a cegueira racial pressupõe que, ser identificado racialmente, é uma questão de vergonha e que os brancos não possuem raça. O silêncio bem intencionado constitui o silêncio da solidariedade branca racial (Sleeter, 1996) e constitui uma outra maneira das crianças crescerem de acordo com regras de como se tomar o elevador das relações raciais.

O privilégio de "não perceber" a raça é um luxo que as pessoas de cor não podem ter, porque elas devem se defender proativamente contra as consequências de suas posições na ordem racial entre "outros" rebaixados nas margens do poder; sua vida pode literalmente depender de sua consciência racial. As inclinações individuais, institucionais e culturais mal dão a elas descanso suficiente de ter que "lidar com" a raça todos os dias. A cegueira racial, apesar de suas boas intenções, é, portanto, condescendente: nega as realidades da raça e do racismo, não reconhece a situação racial da própria branquidade e não compreende que as pessoas de cor (como os deficientes) não apreendem seu mundo como necessariamente deficiente, carente ou vergonhoso. A cegueira racial espera escapar da dor e da ansiedade de lidar com a raça, não tanto pelo benefício das pessoas de cor, mas pelo benefício dos próprios brancos. Para os interesses da supremacia racial, basta supor que cada percepção ou menção da raça é inofensiva ou apenas invoca a raiva cultural negativa e dolorosa da história de nossa nação. A aparente cordialidade da cegueira racial mascara um medo branco, do qual "perceber a raça" é sinal de "ser racista". Portanto, os brancos fingem que "não percebem" a raça para demonstrar sua bondade e escapar do problema. As pessoas de cor geralmente consideram desrespeitosas as alegações dos brancos sobre a cegueira racial. A partir do centro de nossa própria existência, elas se orgulham de si mesmas e de seu grupo; as pessoas de cor querem sua identidade reconhecida, respeitada e honrada. Não ter raça na América não é uma opção (West, 1993) e, portanto, o desafio é desenvolver uma postura diferente em relação à raça de modo a incorporar a confessada crítica da cegueira racial da supremacia racial e o respeito que ela busca aos indivíduos. Uma compreensão mais adequada sobre raça começa com uma visão racialmente sensível.

\section{Sensibilidade racial}

Ser racialmente sensível é perceber que a identidade é (em parte) construída por meio da raça, portanto, não perceber a raça desrespeita as pessoas. Não mais envolvida numa negação ansiosa do que é evidentemente percebido ou temeroso de que todo o reconhecimento racial constitui uma confissão de racismo (Roman, 1993), a sensibilidade racial, ao contrário, reconhece explicitamente que a raça é socialmente e 
${ }^{7}$ Um relato brilhante de transição da abordagem racialmente cega para a racionalmente sensível é dado por Vivian Paeys em experiências no ensino de jardim de infância (1979/1989)

${ }^{8}$ A ação afirmativa, sem dúvida alguma, é aplicada de forma mais ampla do que a raça, em particular no que diz respeito ao gênero. culturalmente importante e explora de forma ampla como a raça se inclui na autocompreensão. A sensibilidade racial reconhece que a raça diz algo positivo sobre todas as pessoas e deve ser comemorada, honrada e levada em consideração se as pessoas têm que ser tratadas com justiça e respeito. ${ }^{7}$ Essa posição justifica as políticas de ação afirmativa e a maior parte da educação multicultural, embora enfrente dificuldades próprias.

A ação afirmativa ${ }^{8}$ tem como premissa a necessidade do reconhecimento da raça para as políticas públicas e educacionais voltadas para remediar a discriminação histórica e atual, embora o pressuposto seja de que as políticas e procedimentos neutro-raciais devam prevalecer uma vez que o tratamento faça efeito total (Appiah, Gutmann, 1996). As posições neutro-raciais e racialmente cegas pretendem tratar os indivíduos de forma igual e justa desconsiderando a raça; entretanto, a neutralidade racial pelo menos reconhece a importância da existência social da raça. Contudo, as duas visões chegam funcionalmente ao mesmo ponto no atual contexto cultural. Faz-se necessária uma maneira de considerar a raça positivamente para responder adequadamente à injustiça racial, embora acadêmicos e juristas lutem para fornecer uma teoria consistente para orientar a política e implementação de ação afirmativa e para responder às críticas instrumentais e morais levantadas pelos opositores (Ezorsky, 1991; Moses, 2002). Permanece verdadeiro o fato de que, numa sociedade justa, os argumentos de considerar a raça na distribuição de benefícios enfrentariam uma carga particularmente pesada de persuasão moral e jurídica.

O legado da supremacia racial varia do nível de injustiça e do tratamento brutal aos danos sutis e escondidos às pessoas de cor, gerando uma poderosa demanda moral por respostas corretivas. Mesmo assim, as bases éticas para a ação afirmativa racialmente sensível são bem sucedidas apenas na medida em que fornecem uma compensação justa para a injustiça e criam as condições mínimas para uma sociedade racialmente imparcial. O pressuposto de que a justiça exige tratamento igual entre os indivíduos e a neutralidade oficial em relação à raça virtualmente em todas as situações de política e ação pública consiste num poderoso suporte para as bases da justiça liberal democrática. Esses padrões primários restringem o apoio aos princípios racialmente sensíveis e levantam questões persistentes a fim de assegurar que os meios para se atingir os objetivos de ação afirmativa sejam no mínimo ofensas possíveis e que os benefícios alcancem os recipientes pretendidos e reduzam a necessidade de tais programas. Levar a raça em consideração (mesmo de formas positivas para propósitos éticos) pode atribuir muita importância à raça e, não intencionalmente, regravar a supremacia racial. Essa questão somente pode ser afastada mediante a evidência de que as políticas e procedimentos neutro-raciais deixem intacta uma ordem racial injusta e difícil de ser aperfeiçoada.

A educação multicultural constitui outro amplo domínio de política e prática racialmente sensíveis implementadas para essas questões predominantes e contra críticas similares. Trata-se de um campo difuso 
que carece de fundamentos teóricos claros (Willett, 1998), esforços têm sido feitos para categorizar essa educação historicamente (Banks, 1993) e tematicamente (Sleeter, Grant, 1987), bem como para situá-la politicamente (Mccarthy, 1993; Sleeter, Mclaren, 1995). O que parece claro, entretanto, é que a educação multicultural constituiu uma reação contra os pressupostos de supremacia racial ignorados no currículo escolar e nas atitudes e comportamentos dos professores; contra essas inadequações, a educação multicultural alega que teve as melhores intenções. Eles queriam homenagear o pluralismo americano expandindo o currículo com ofertas representativas do amplo escopo das culturas e raças que povoam nossa nação e que contribuem para o pensamento da vida americana. A educação multicultural certamente prestou um grande serviço introduzindo uma gama de cores e diversas perspectivas no tradicional monocromático e monocular cânone oficial das escolas. Entretanto, as limitações teóricas e curriculares do multiculturalismo racialmente sensível são questões separadas desse serviço e dessas boas intenções.

Algumas abordagens enfatizam o entendimento das diferenças e o aperfeiçoamento das relações intergrupos e incentivam o conhecimento das próprias origens culturais das pessoas, o conhecimento e o respeito por pessoas de backgrounds diversos e as interações interpessoais positivas (Nieto, 1999). As escolas procuram cultivar a competência transcultural e preservar a diversidade como recurso para o desenvolvimento individual e social. Entretanto, embora construtivas, essas abordagens se voltam para o pluralismo e para as diferenças raciais por meio de lentes cor-de-rosa. Elas geralmente falham ao abordar os conflitos entre e dentro dos grupos, deixando de examinar como esses conflitos impactam a organização social, educacional, econômica e política da nação (Nieto, 2004). Também tendem a supor que as origens e as causas do racismo e da injustiça estão dentro de um sistema de valores ou da base de conhecimento do indivíduo, deixando, portanto, de considerar as dimensões sistêmicas e históricas dos conflitos e lutas raciais e étnicas (Walzer, 1998). O fato é que os grupos raciais e étnicos não competem numa mesma posição em arenas públicas neutras. Ademais, a educação multicultural racialmente sensível deixa de abordar as tensões persistentes geradas pelos esforços para moldar a coesão social nacional, embora respeitando e mantendo também as particularidades da diversidade cultural e racial (Appiah, 1997); ela obscurece, no interesse da civilidade e da paz na sala de aula, as políticas de reconhecimento e a posição política subjacente a ela (Gutmann, 1994; Taylor, 1992).

A maior parte da educação multicultural racialmente sensível interpreta erroneamente as identidades raciais como diferenças naturais entre grupos culturais e raciais homogêneos que se desenvolvem em seus próprios termos ou como resultado de escolhas individuais; ela não expõe e problematiza as bases de identidades raciais e étnicas constituídas historicamente e as relações de poder subjacentes a elas (Roseberry, 1992). Enquanto as identidades são vistas como criadas dentro e por meio de fronteiras culturais e raciais neutras, as diferenças, que constituem efeitos 
${ }^{9}$ Paley (1979/1989, p. 135) reconheceu que ela cometeu este erro de supergeneralização. do racismo, são atribuídas a variáveis culturais e raciais mutuamente excludentes, sem intenção de reescrever a supremacia racial na forma de um "racismo diferencialista" (Balibar, 1991). Educadores bem-intencionados que procuram ser sensíveis aos backgrounds raciais dos alunos geralmente racializam o significado dos comportamentos ${ }^{9}$ e trocam efeitos por causas, isto é, eles interpretam os comportamentos dos alunos (representações, práticas, linguagem) mais como atributos raciais ou culturais inerentes do que como o resultado da injusta escola competitiva e das relações de poder na sociedade (Giroux, 1992). Essas diferenças raciais naturalizadas revelam uma forma "leve" de essencialismo (distinto do essencialismo "pesado" da supremacia da raça), desconsiderando as lutas ideológicas que de fato as fazem emergir.

Alguns tipos de educação multicultural são focados na história e na política das relações raciais e buscam metas emancipatórias de maior poder econômico e social para grupos desfavorecidos (Sleeter, 1991; Sleeter, Mclaren, 1995). A lógica é que um currículo mais relevante e menos alienante aumentará o comprometimento e o sucesso acadêmico do aluno, o que dará mais oportunidades de trabalho para os alunos de cor. Entretanto, a pressão a favor do currículo preparado, padronizado e articulado para testar mandatos reduziu até mesmo essas modestas aberturas (Mcneil, 2000), e a fé nas qualidades redentoras do sistema escolar minimiza o grau por meio do qual o sistema está estruturalmente dirigido em ideologias dominantes e desigualdades econômicas (Lipman, 2004). A posição escolar e os regimes de classificação tendem a reproduzir as relações de classe, gênero e raça e a reduzir as oportunidades econômicas e políticas (Dornbush, Glasgow, Lin 1996), independentemente do conteúdo curricular. Ademais, a esperança de que o sucesso da educação superior leve a empregos significantes reflete "uma ingenuidade particular sobre o caráter racial do mercado de trabalho... [enquanto] ficam subenfatizadas as relações estruturais e materiais dentro das quais a dominação racial está inserida" (Mccarthy, 1988, p. 269). Isso não significa que raça e racismo sejam simplesmente características secundárias do capitalismo (Miles, 1989, 1993), ao contrário, já que o próprio racismo ajuda a moldar o mercado de trabalho, as forças do mercado podem absorver mais realizações e oportunidades expandidas sem alterar as relações econômicas estruturais entre as raças (Carnoy, 1994; Wilson, 1987).

Como o pêndulo oscila entre os polos de a raça diz tudo e a raça não diz nada e fica estável na posição a raça diz coisas positivas, as vantagens são promissoras mas longe de serem suficientes. As abordagens racialmente sensíveis contribuíram para ganhos substanciais nas escolas e na educação mais ampla, mas elas inadvertidamente reforçaram algumas construções raciais essencialistas da supremacia racial e enfraqueceram certos princípios de justiça. A educação racialmente sensível, como materializada em esforços de ação afirmativa ou abordagens culturais, não pode desafiar o sistema escolar que continua a desfavorecer os alunos de cor, reproduzindo e legitimando as desigualdades que preveem seus fracassos (Conforti, 1992) e estimulam sua resistência (Kohl, 1994). 


\section{Crítica racial}

O "essencialismo leve" da sensibilidade racial se compromete muito ao subestimar a raça; um olhar mais crítico mostra que a raça revela coisas contraditórias e alguma coisa diferente em lugares e épocas diferentes. A perspectiva racialmente crítica reconhece que as qualidades aparentes específicas dos grupos raciais não são absolutamente definidas e estão num estado de fluxo contínuo; ela foca na formação racial em contraste com um background de forças sociais, culturais, políticas e econômicas (Omi, Winant, 1994; Winant, 1994). Isto é, a raça é algo que nós fazemos e algo que é feito a nós, em vez de algo que nós somos (Bernasconi, 2001; Boxill, 2001). A raça não é uma característica natural ou biológica das pessoas ou de grupos, mas sim um princípio estruturante que informa como os grupos interagem e fornece normas e padrões dentro dos quais os indivíduos fazem escolhas sobre suas próprias identidades. ${ }^{10}$ Os imigrantes europeus não necessariamente desembarcaram nestas praias como brancos e a sua assimilação quanto à branquidade prosseguiu ao longo de caminhos competitivos específicos que construíram a "etnia" (Jacobson, 1998; Waters, 1990). Da mesma forma, imigrantes africanos, asiáticos, latinos e sulamericanos participaram de encontros típicos com a americanização que os racializou e os diferenciou dos brancos (Appiah, 1997). Como um processo competitivo de identidade ideológica, a formação racial ocorre dentro de uma matriz de disputa de interesses e poder, de forma que as fronteiras do que seja negro, branco, etc, inexoravelmente mudam com os contextos sociais e culturais, independentemente da validade científica, teológica ou filosófica da raça per se. Portanto, a resistência à raça pode coexistir com o reconhecimento da formação da identidade racial (Appiah, Gutmann, 1996).

A identidade racial não é um princípio básico conhecido. Como as regras para se tomar o elevador, as identidades raciais ganham os indivíduos e grupos mesmo quando são ganhas pelos indivíduos e grupos. Os debates e lutas que as definem ocorrem dentro dos processos dinâmicos entre as agências governamentais, legislaturas, tribunais, escolas, igrejas, mídia e outras instituições, assim como entre os indivíduos. A formação racial incorpora contradições, descontinuidades e multiplicidades que refletem as relações desiguais de poder e as normas competitivas dentro e entre supostos grupos raciais (Dyson, 1996/1997). A perspectiva racialmente crítica reconhece que cada raça contém uma diversidade muito sólida produzida pelos efeitos interativos com outras forças estruturantes de identidade, tais como linguagem, classe, gênero, orientação sexual, habilidades ou religião. Por exemplo, as interações de classe e raça aparecem sob o rótulo pejorativo de "lixo branco", que coloca alguns brancos como equivalentes às pessoas de cor (Wray, Newitz, 1997).

Ser racialmente crítico é ver esse processo de formação de identidade onde os outros veem raça. A posição racialmente crítica concede a cada pessoa sua particularidade em relação às normas e aos padrões dominantes dentro e entre as raças. O pressuposto é de que somente a raça $\overline{10}$ Classe e gênero constituem estruturas ideológicas similares. 
${ }^{11}$ A "regra de baixa-descendência" deu crédito à raça de acordo com o ancestral mais baixo no ranking de uma pessoa. Esta "regra one-drop" historicamente significava que um único ancestral negro tornava a pessoa completamente negra. Ironicamente, isto criou certa solidariedade dentro da comunidade negra apesar das questões contenciosas referentes aos indivíduos "misturados". (especialmente entendida como "o lado de fora") não garante o conhecimento essencial sobre uma pessoa específica. O significado de raça para uma pessoa emerge das interações específicas dela com os significados ideologicamente competitivos de raça no contexto social e cultural mais amplo (Schneider, 1997; Thompson, Sangeeta, 1996).

As abordagens da supremacia racial alegam que a raça é uma constante determinada por decreto divino ou pela biologia e isto diz tudo. O reconhecimento de uma ou outra raça é absoluto. ${ }^{11}$ A cegueira racial (na sua boa fé) não compartilha essas visões e fornece um poderoso padrão moral para as sociedades democráticas pluralísticas no seu desejo de ignorar a raça em relação à equidade e à justiça para todos. Mas a cegueira racial pressupõe que conhecemos muito pouco sobre uma pessoa a partir de sua suposta raça, portanto, a sensibilidade racial coloca um brilho positivo sobre a contribuição da raça para a identidade de uma pessoa e de políticas justas, apesar dos seus próprios traços remanescentes de pressupostos da supremacia racial. A visão racialmente crítica sustenta que a raça é de fato um fator importante na sociedade e na vida dos indivíduos, mas a importância da raça na identidade pessoal de uma pessoa é determinada pela sua história de vida específica situada dentro de contextos sociais e culturais mais amplos. Considerando-se que a raça nada diz sobre si mesma, o olhar é dirigido a outro lugar, para o background de significado que faz com que ela se destaque como tal. Esse foco ilumina os processos dialetais internos e externos de afirmações e denúncias que estabelecem as normas racializadas do que significa ser de uma raça ou de outra. Os grupos que detêm o poder social, econômico e político inibem possíveis autoentendimentos impondo definições mediante expressões literárias e culturais (Morrison, 1992), padrões institucionais e operações, propagação em massa de estereótipos e declarações legais. As consequências das definições legais impostas de membro de grupo racial são independentes das autodefinições e podem mudar a vida: consideremos as leis de pureza sanguínea nazistas que determinaram a identidade dos judeus, ou as leis americanas estabelecendo quocientes de sangue para registro de membro nas tribos nativo americanas ou ainda leis definindo e transferindo crianças negras para escolas segregadas. Esses mecanismos e interações cotidianos comuns mantêm e explicam a natureza das ordens sociais de forma a distorcer sua construção histórica.

Grupos lutam nas fronteiras raciais externas para resistir às definições impostas e para ser independentemente autodeterminantes. As lutas para estabelecer suas próprias normas de inclusão são igualmente difíceis e dolorosas. Debates persistentes sobre o status da identidade de pessoas interraciais revelam os profundos riscos psicológicos, sociais, econômicos e políticos envolvidos (Funderburg, 1994; Root, 1996; Wallace, 2001; Zack, 1993). As categorias raciais mudaram a cada censo americano, destacando a natureza ideológica da formação racial. Com uma ideologia dominante de que "ser americano é ser branco" como pano de fundo, a dialética da identidade racial possui uma trajetória histórica sugerida por esta pequena amostra de termos: Negro [negro], Black [preto], African-American 
[afro-americano]; Hispanic [hispânico]; Mexican American [mexicano americano], Chicano, Xicano, Latino, New Yorican [nova-iorquinos vindos da Costa Rica]; American [americano], White [branco], European American [europeu americano], Anglo; Indian [índio], Native American [americano nativo], Indigenous Americans [americanos autóctones], First Natives [primeiros nativos], Navajo [Diné], Sioux [Lakota]; Oriental, Asian American [americano asiático], Japanese American [americano japonês], Chinese American [americano chinês]. Esses "nomes" constituem forças poderosas que marcam momentos inesquecíveis do desenvolvimento pessoal (Thompson, Sangeeta, 1996).

As fronteiras raciais exigem que alguns membros de grupos policiem as fronteiras em ambos os lados que eles dividem. As patrulhas da fronteira branca podem invocar fortes depreciações raciais para definir um "outro" pejorativo: nigger [negro], spic [hispânico], greaser [mexicano], wetback [mexicano], redskin [americano nativo], jap [japonês], chink [chinês]. Uma força parecida, mas muito menos poderosa, é mostrada aqui: honky [branco], cracker [branco pobre], gringo [estrangeiro], wasichu [branco, para índios Lakota], whitey [branco, para afro-americanos]. Mas a maioria das regras de como tomar o elevador das ordens raciais é mantida por meio de pressões mais sutis, embora ainda coercitivas, que desafiam os desvios das normas. O namoro e o casamento interraciais enfrentam olhares e gestos céticos ou hostis 40 anos após a Suprema Corte derrubar todas as leis antimiscigenação; a pergunta pejorativa e coercitiva "Porque você está tentando agir como um branco (negro)?" constitui outra efetiva intimidação de fronteira. As pessoas de cor usam descrições de comida para rotular pejorativamente a assimilação à qualidade de ser branco e a pressionar o desobediente a voltar para sua terra natal: oreo, côco, maçã, banana. As atividades comuns linguísticas, sociais e culturais inscrevem a raça a partir de como as pessoas andam, falam, vestem, comem, saem, ouvem ou fazem música, ou até fazem amor. Todos esses processos de formação racial são ressaltados dentro de uma perspectiva racialmente crítica e a raça simplesmente desaparece.

A formação racial destaca o fato de que toda pessoa individual está mais ou menos distante das normas da ordem racial (se definidas interna ou externamente), o distanciamento é uma característica de todas as identidades raciais (Glass, 2000a), além de estas serem sempre fluidas. Alguns consideram isso um processo de desenvolvimento psicossocial com estágios distintos (Derman-Sparks, Phillips, 1997; Helms, 1992; Tatum, 1997), mas, mesmo questionável, o dinamismo da identidade racial é aparente e os modelos de estágio podem ser úteis heuristicamente. As raças não existem como entidades biológicas, sociais ou culturais, e a identidade racial surge das interações normativamente competitivas. Cada identidade racial particular do indivíduo é apenas parcialmente moldada a partir do centro de seu autoentendimento, já que ele está limitado dentro de fronteiras ideologicamente infusas fora de seu controle. Existem várias maneiras de habitar e ser habitado pelas identidades raciais e não pode haver um self autêntico fora desses processos de formação. A raça 
é algo que fazemos e algo que é feito a nós, não algo que somos. Ela é construída culturalmente e historicamente e revela coisas contraditórias.

\section{Antirracismo}

A investigação da formação da identidade racial revela a política de poder persistente que leva a perspectiva racialmente crítica em direção à ação antirracista. Grupos racialmente identificados estão inseridos dentro das injustiças estruturais nos domínios sociais, culturais, políticos e econômicos, o que distorce a dinâmica entre e dentro do grupo no centro da formação racial, isto é, o racismo já molda os processos e o contexto de formação racial. Portanto, a raça é um tipo de consequência do racismo e constitui, na verdade, um dos seus efeitos mais notáveis. O que está sendo feito sobre o retrato da raça (às vezes mesmo enquanto desafiamos essas mesmas estruturas) reforça as estruturas ideológicas que privilegiam certos grupos.

Não há nenhuma razão a priori para dividir a população mundial em raças, em quatro, cinco ou qualquer outro número; não existe um modo conhecido para categorizar as pessoas pela cor da pele, características faciais, textura do cabelo ou quaisquer outros supostos aspectos distintivos de raças. No nível genético microscópico, há muito menos diferenças do que as proclamadas pela variação fenotípica (Graves, 2001). O olhar voltado para a teoria (do racismo) sobre a heterogênea e polimorfa população humana considera raças distintas onde há apenas uma: a raça humana. O racismo cria raças e mantém as pessoas dentro delas por meio de processos de ordenamento que distribuem privilégios sociais e benefícios econômicos e políticos. Um entendimento racialmente crítico revela a luta contra o racismo, ao passo que um comprometimento sustentado ao trabalho antirracismo desconstrói o significado e a importância da raça.

A abordagem da cegueira racial de "não ver, ouvir, falar sobre a raça" adota uma postura defensiva evitando os desafios do racismo. O esforço para ser respeitoso e justo com todas as pessoas e para diminuir os significados da supremacia racial fornece motivações morais profundas para a cegueira racial. Entretanto, o resultado nega que a raça faça contribuições positivas dentro da experiência das pessoas de cor, e, portanto, ofende onde se pretendia ter respeito, sendo que deixa também intacta uma forma silenciosa de supremacia racial. A sensibilidade racial corrige o primeiro desses defeitos, mas, novamente, reinscreve alguns pressupostos da supremacia racial com um "essencialismo leve". As duas visões teorizam pouco sobre raça e pouco fazem para destruir o racismo. Todas essas deficiências são superadas na visão crítico racial antirracista enquanto os resultados positivos e intenções morais são fortalecidos. A ação se torna estrategicamente dirigida à destruição da estrutura do racismo. A garantia moral dessas ações autoriza a uma pessoa a dizer NÃO para raça e SIM para cor; esta recusa, diferente daquela da visão da cegueira racial, é adquirida por meio do trabalho difícil e perigoso de 
transformar uma sociedade racista. Quanto mais nos confrontarmos e invertermos o racismo, menos importância a raça terá.

Alguns "novos abolicionistas" clamam por ações que interrompam as operações normativas da ordem racial sob o slogan "a traição à branquidade é a lealdade à humanidade" (Ignatiev, Garvey, 1996, p. 10) e abraçam a cultura "incontestavelmente mulata" (p. 20) que constitui a única verdade racial histórica da identidade americana. Esse tipo de ação subversiva perturba a solidariedade silenciosa dos brancos que mantêm o privilégio racial (Sleeter, 1996). Para ser bem sucedida, entretanto, a luta contra o racismo deve ter uma frente e um objetivo mais amplos. O racismo não pode estar divorciado do sexo e da opressão de classe (Davis, 1981; Hooks, 1990; Zack, 1997), já que ele invade os domínios psíquicos profundos dos desejos, medos e instintos básicos (Lane, 1998). O legado da supremacia racial alcança desde os estados mais íntimos e sagrados até aqueles mais públicos e profanos de nossas vidas; ele contamina as instituições sociais, culturais, educacionais, econômicas e políticas e permeia a vida cotidiana. Mas as particularidades da existência e das estruturas ideológicas da cultura devem ser desafiadas para revelar as complexidades e os traços da supremacia racial, e apenas intervenções estratégicas oferecem uma promessa genuína de superar os muitos obstáculos à justiça.

\section{Educação racialmente crítica e antirracista}

Embora a educação não possa fazer tudo, ela ainda pode fazer muitas coisas, e deve fazer alguma coisa, na luta contra o racismo. A ordem racial recebe ajuda e sustentação por meio de operações escolares, relações sociais e conteúdo curricular, e cada um desses domínios exige intervenções transformadoras, assim como os programas de formação docente. Mas a formação racial ocorre em muitos outros espaços educativos onde as crianças e os jovens se engajam em atividades atléticas, musicais, espirituais, culturais, sociais e políticas, e a educação racialmente crítica e antirracista traz essas zonas de construção de identidades (Weis, Fine, 2000) para dentro do círculo de seu projeto também. Cada um desses locais institucionais formais e informais deve aceitar um papel importante a fim de superar a supremacia racial e se aliar a lutas sociais, culturais e políticas mais amplas.

A educação racialmente crítica e antirracista tem objetivos mais amplos e mais profundos do que as abordagens da cegueira racial ou da sensibilidade racial. Ela tem um comprometimento sério e estratégico de transformar vidas e a sociedade em geral eliminando a doença do racismo que infecta a cultura; ela não se satisfaz em salvar as feridas da injustiça. Programas com base nos pressupostos da cegueira racial e da sensibilidade racial falharam por décadas em lidar com as bases da raça e do racismo. As reformas escolares que não enfrentam as questões sociais, econômicas e políticas associadas ao contexto urbano provaram 
não ser capazes de atingir ganhos substantivos nas vidas dos estudantes de cor (Anyon, 1997), mesmo quando as reformas foram apoiadas pelas administrações escolares e civis lideradas por pessoas de cor (Henig, Hula, Orr, Pedescleaux, 1999). Em face dos resultados frustrantes que surgiram dos enormes recursos destinados a metas limitadas, é hora de questionar essas metas e mudar os esforços para campanhas mais abrangentes.

Programas de formação docente, apesar de hoje em dia algumas vezes exigirem um curso de educação multicultural, raramente examinam a dinâmica racial subjacente a maior parte de seu assunto (Mccarthy, 1990; Mccarthy, Crichlow, 1993). Eles falharam em preparar os professores para investigar como as políticas e procedimentos escolares contradizem suas boas intenções de serem justos com todos os alunos, bem como em preparar os professores a suspeitarem de todas as descrições racializadas de aprendizagem ou de comportamentos do aluno. A educação racialmente crítica e antirracista questiona os limites das abordagens racialmente críticas e da sensibilidade racial e estimula ativamente o processo de desaprender o racismo (Cochran-Smith, 2000). Isso asseguraria que os cursos de avaliação e experimentação possibilitassem aos professores adotar os argumentos decisivos e as evidências necessárias para expor os padrões do ataque do movimento nas escolas públicas (Berliner, Biddle, 1995) e interromper as altas apostas na experimentação antes que suas consequências previsíveis, mesmo que não intencionais, e negativas causassem mais danos a um grande número de alunos de cor e pobres (Jones, Jones, Hargrove, 2003; Orfield, Kornhaber, 2001). Seria assegurado que os cursos de leitura ministrados examinassem as políticas de letramento (Glass, 2000b; Shannon, 1990, 1998), revelassem os preconceitos linguísticos em relação às origens da supremacia racial (Macedo, 2000) e preparassem os professores para utilizar métodos educacionais que honrassem e dessem autoridade à linguagem dos alunos de cor e pobres (Delpit, Dowdy, 2002; Finn, 1999). Também garantiria que os professores refletissem criticamente na sua própria formação racial (DermanSparks, Philips, 1997; Sleeter, 1993) e desenvolvessem a capacidade de elaborar aulas e currículos contra o preconceito (Derman-Sparks, ABC Task Force, 1989; Schniedewind, Davidson, 1998). Reconstruindo as bases dos programas educacionais docentes com objetivos emancipatórios e críticos, os professores poderiam entender e atuar dentro do seu papel principal nas lutas por justiça (Cochran-Smith, 2004; Darling-Hammond, French, Garcia-Lopes, 2002). A pedagogia engajada da educação crítica racial antirracista conecta os programas de formação docente diretamente às escolas que servem a alunos de baixa renda, cultural e linguisticamente diversos, e a suas comunidades maiores, não apenas para fortalecer o sucesso do aluno e melhorar o seu desenvolvimento profissional, mas também para construir uma democracia justa (Glass, Wong, 2003).

Um programa de formação docente racialmente crítico e antirracista ajudaria a promover os ambientes de aprendizagem na educação básica combatendo o estereótipo racial, estabelecendo o respeito, garantindo a segurança para as diversas maneiras de ser e proporcionando um 
currículo relevante às experiências, histórias e aspirações de todos os alunos. A partir das primeiras séries em diante, os alunos estudariam a formação racial como um aspecto da produção histórica de representação e identidades dentro de contextos políticos altamente competitivos. Os processos sociais e culturais explícitos e implícitos que dão nome e inibem as identidades seriam revelados, estudados e desconstruídos. O discurso e as imagens racializadas na mídia e na cultura popular, assim como na conversa cotidiana e na brincadeira dos alunos, seriam analisados para reduzir seu poder definidor. Uma educação racialmente crítica e antirracista ligaria esta "liberação de identidade racial" (Giroux, 1997) a lutas mais amplas contra a discriminação e a desigualdade racial, e os alunos teriam uma ampla variedade de contatos aprofundados progressivamente com organizações ativistas e com as comunidades-dentro-de-comunidades pluralísticas que elas servem. Ao estudar a história da resistência à ordem social, os alunos aprenderiam estratégias e táticas que poderiam ser distribuídas nas lutas atuais e também sentiriam orgulho pelo fato de que pessoas de todas as supostas raças e de todas as formas de vida contribuíram para construir uma nação de igualdade e justiça (Brown, 2002; Salomon, 1998). Esse tipo de educação proporciona aos alunos maior liberdade para formar identidades, não racializadas e definidas por relações de dominação, mas sim moldadas por seus interesses, talentos e habilidades; ela também proporciona aos alunos as capacidades e competências necessárias para reconstruir a sociedade e participar totalmente da democracia, estendendo no futuro aquelas ainda pequenas vozes e bravas ações de incontáveis cidadãos morais que os precederam.

Ao praticar a ruptura da ordem racial de senso comum inserida no mundo cotidiano da sala de aula, da escola e da sociedade, professores e alunos realizam engajamentos civis e políticos e modos éticos de questionamento e confronto necessários para uma democracia vibrante. A prática gera mais prática e, com o passar do tempo, professores e alunos poderiam desenvolver os comprometimentos mutantes de vida de luta não violenta por uma justiça implícita, superando a supremacia racial na intimidade de relações pessoais, nas operações das instituições e nos significados culturais que moldam a história. Como a educação racialmente crítica e antirracista integra o ambiente de aprendizagem das escolas e universidades a outros espaços educativos, ela ajuda as comunidades a dar as costas a uma política de culpa racial e de raiva moral e se voltar para a responsabilidade e a prestação de contas. Nenhum de nós é culpado por viver numa sociedade racialmente ordenada ou por ser habitada por suas "regras de como tomar o elevador". Isso é simplesmente uma sina histórica que impacta negativamente cada pessoa, grupo e instituição (embora de importantes maneiras diferentes). A culpa é pessoal, não hereditária, e é dirigida ao conhecimento ou à ação negligente. A responsabilidade é inevitável, já que cada ação ou cria injustiça novamente ou procura transformá-la.

Portanto, a finalidade da educação racialmente crítica e antirracista não é identificar e indiciar os racistas, mas sim permitir que cada pessoa assuma a responsabilidade para a transformação da ordem racial sempre 
que ela afetar a sua própria vida. O objetivo é construir uma comunidade dentro da qual o diálogo e a ação racialmente crítica e antirracista prosperem, porque eles não se referem à culpa, mas a estabelecer respeito, oportunidade igual e uma democracia robusta e justa. Ser responsável no sentido racialmente crítico e antirracista significa incorporar uma resposta sincera à dificuldade daqueles menos afortunados devido às tradições da supremacia racial e, também, incluir um esforço comprometido para mudar tudo o que estiver ao seu alcance. É aceitar que não existe um fim para que oportunidades intervenham contra o racismo de forma ética e socialmente transformadora.

A responsabilidade gera a prestação de contas, que na educação crítica antirracista exige uma revisão pública do grau por meio do qual os programas de formação docente, escolas e outros espaços jovens minimizam os traumas e as deformações da formação racial e maximizam a busca pelo desenvolvimento da identidade baseada em interesses, ganhos e talentos. Faz-se necessária uma revisão pública do grau pelo qual as escolas e outras instituições sociais e culturais promovem o desenvolvimento de cidadãos críticos que fazem comprometimentos eternos a um tipo de "psicanálise histórico-cultural e político", desafiando os limites de seus lugares sagrados mais privados e também das arenas comunitárias. A justiça é alcançada apenas por meio de ações realizadas todos os dias; a educação racialmente crítica e antirracista conclama cada um de nós para essa responsabilidade. Uma vida política ética não permite espectadores. Na medida em que avanços contra o racismo são realizados pela intenção, palavra e ação, também serão feitos em outras fontes múltiplas onde a opressão impede a realização de uma democracia justa. Cada um de nós tem mais poder do que imaginamos se simplesmente invocarmos a coragem para falar e agir diante das injustiças comuns e das desigualdades do cotidiano. A educação racialmente crítica antirracista fornece as experiências necessárias como base para ação corajosa, sendo que, ao ligar as pessoas à história de lutas por justiça e a cada um para que as lutas continuem, ela traz o sonho de uma democracia justa mais perto de realização.

\section{Referências bibliográficas}

ABOUD, F. E.; DOYLE, A B. The early development of ethnic identity and attitudes. BERNAL, M. E.; KNIGHT, G. P. (Org.). In: Ethnic identity. Albany, NY: State University of New York Press, 1993. p. 46-59.

ANYON, J. Ghetto schooling: a political economy of urban educational reform. New York: Teachers College Press, 1997.

APPIAH, K. A. The multiculturalist misunderstanding. New York Review of Books. 9 out. 1997. Disponível em: <http://www.nybooks. com/articles/archives/1998/mar/05/the-multiculturalist-misunderstanding/ ?pagination $=$ false $>$. 
APPIAH, K. A.; GUTMANN, A. Color Conscious: the political morality of race. Princeton: Princeton University Press, 1996.

BALDWIN, J. A talk to teachers. SIMONSON R.; WALKER, S. (Org.). In: Multicultural literacy. Saint Paul, MN: Graywolf Press, 1988. p. 3-12.

BALIBAR, E. Is there a neo-racism? In: BALIBAR, E.; WALLERSTEIN, I. (Org.) Race, nation, class: ambiguous identities. London: Verso, 1991. p. 17-28.

BANKS, J. A. Multicultural education: development, dimensions and challenges. Phi Delta Kappan, p. 22-28, Sept., 1993. Disponível em: <http://www.jstor.org/discover/10.2307/20405019?uid=3737664\&uid $=2129$ \&uid $=2 \&$ uid $=70 \&$ uid $=4 \&$ sid $=47699134193787>$.

BERLINER, D.; BIDDLE, B. The manufactured crisis: myths, fraud and the attack on America's public schools. Reading, MA: Addison Wesley, 1995.

BERNASCONI, R. Race. Oxford: Blackwell Publishers, 2001.

BIALE, D.; GALCHINSKY, M.; HESCHEL, S. (Org.). Insider/Outsider: American Jews and multiculturalism. Berkeley: University of California Press, 1998.

BLUM, L. Moral asymmetries in racism. BABBITT, S.E.; CAMPBELL, S. (Org.). In: Racism and philosophy. Ithaca, NY: Cornell University Press, 1999.

BOXILL, B. (Org). Race and racism. Oxford: Oxford University Press, 2001.

BROWN, C. S. Refusing racism: white allies in the struggle for civil rights. New York: Teachers College Press, 2002.

CARNOY, M. Faded dreams: the politics and economics of race in America. New York: Cambridge University Press, 1994.

COCHRAN-SMITH, M. Blind vision: unlearning racism in teacher education. Harvard Educational Review, v. 70, n. 2, p. 157-190, 2000. Disponível em: <http://courses.ttu.edu/rsheets/DIVk/seminar\%20 materials/Cochran-Smith-2000-Blind\%20Visoin.pdf $>$.

Walking the road: race, diversity, and social justice in teacher education. New York: Teachers College Press, 2004.

COMER, J. P. Racism and the education of young children. Teachers College Record, v. 90, n. 3, p. 352-361, 1989. 
CONFORTI, J. M. The legitimation of inequality in American education. Urban Review, v. 24, n. 4, p. 227-238, 1992.

D'SOUZA, D. Illiberal education: the politics of race and sex on campus. New York: Free Press, 1991.

DARLING-HAMMOND, L.; FRENCH, J.; GARCIA-LOPEZ, S. P. (Org). Learning to teach for social justice. New York: Teachers College Press, 2002.

DAVIS, A. Women, race and class. New York: Random House, 1981.

DELGADO, R.; STEFANCIC, J. (Org.). Critical white studies. Philadelphia: Temple University Press, 1997.

DELPIT, L.; DOWDY, J. K. (Org.). The skin that we speak: thoughts on language and culture in the classroom. New York: The New Press, 2002.

DERMAN-SPARKS, L.; A.B.C. TASK FORCE. Anti-bias curriculum: tools for empowering young children. Washington, D.C.: National Association for the Education of Young Children, 1989.

DERMAN-SPARKS, L.; PHILLIPS, C. B. Teaching/learning anti-racism. New York: Teachers College Press, 1997.

DERMAN-SPARKS, L.; HIGA, C. T.; SPARKS, W. Children, race and racism: how race awareness develops. Interracial Books for Children Bulletin, v. 11 n. 3-4, p. 3-9, 1980.

DORNBUSCH, S. M. Off the track: presidential address, annual meeting of the Society for Research on Adolescence. San Diego, February, 1994.

DORNBUSCH, S. M.; GLASGOW, K. L.; LIN, I. C. The social structure of schooling. Annual Review of Psychology, v. 47, p. 401-429, 1996.

DYSON, M. E. Race rules: navigating the color line. New York: Random House Vintage Books, 1996/1997.

EARLY, G. (Org.). Lure and loathing: essays on race, identity, and the ambivalence of assimilation. New York: Allen Lane, The Penguin Press, 1993.

EZORSKY, G. Racism and justice. Ithaca, NY: Cornell University Press, 1991.

FINE, M. Witnessing whiteness. In: FINE, M.; WEIS, L.; POWELL, L.; MUN WONG, L. (Org). Off white: readings on race, power and society. New York: Routledge, 1997. p. 57-65. 
FINE, M.; WEIS, L.; POWELL, L.; MUN WONG, L. (Org.). Off white: readings on race, power and society. New York: Routledge, 1997.

FINN, P. Literacy with an attitude: educating working-class children in their own self-interest. Albany, NY: SUNY Press, 1999.

FORDHAM, S. Blacked out: dilemmas of race, identity and success at Capital High. Chicago: University of Chicago Press, 1996.

FRANKENBERG, R. The social construction of whiteness: white women, race matters. Minneapolis: University of Minnesota Press, 1993.

FRAZER, S. (Org.). Bell Curve wars: race, intelligence and the future of America. New York: Basic Books, 1995.

FREIRE, P. Pedagogy of the oppressed. New York: Seabury, 1970a.

. The adult literacy process as cultural action for freedom.

Harvard Educational Review. v. 40 n. 2. 1970b, p. 205-225.

. Cultural action and conscientization. Harvard Educational

Review. v. 40, n. 3, 1970c, p. 452-477.

. Pedagogy of hope. New York: Continuum, 1994.

FUNDERBURG, L. Black, White, other. New York: William Morrow, 1994.

GALLUP POLL. Gallup Poll social audit on black/white relations in the U.S. 2004. Disponível em: <www.gallup.com>. Acesso em: 10 jan. 2001.

GLASS, R. D. Education and the ethics of democratic citizenship. Studies in Philosophy and Education, v. 19, n. 3, 2000a, p. 275-296. . Reading Patrick Shannon on reading instruction:

reflections on politics and education. Reading Research Quarterly, v. 35, n. 2, 2000b, p. 284-297. . On Paulo Freire's philosophy of praxis and the foundations of liberation education. Educational Researcher, v. 30, n. 2, 2001, p. 15-25.

GLASS, R. D.; WONG, P. L. Engaged pedagogy: meeting the demands of justice in urban professional development schools. Teacher Education Quarterly, v. 30, n. 2, 2003. p. 69-88.

GIROUX, H. Border crossings: cultural workers and the politics of education. New York: Routledge, 1992. 
GIROUX, H. Rewriting the discourse of racial identity: towards a pedagogy and politics of whiteness. Harvard Educational Review, v. 67, n. 2, 1997. p. 285-320.

GRAVES, J. L. The emperor's new clothes: biological theories of race at the millenium. New Brunswick, NJ: Rutgers University Press, 2001.

GUTMANN, A. Multiculturalism: examining the politics of recognition. Princeton, NJ: Princeton University Press, 1994.

HELMS, J. E. A race is a nice thing to have. Topeka, KS: Content Publications, 1992.

HENIG, J. R.; HULA, R. C.; ORR, M.; PEDESCLEAUX, D. S. The color of school reform: race, politics and the challenge of urban education. Princeton, NJ: Princeton University Press, 1999.

HOOKS, B. Yearning: race, gender and cultural politics. Boston: South End Press, 1990.

HORTON, M. The long haul. New York: Doubleday, 1990.

IGNATIEV, N.; GARVEY, J. (Org.). Race traitor. New York: Routledge, 1996.

JACOBSON, M. F. Whiteness of a different color: european immigrants and the alchemy of race. Cambridge, MA: Harvard University Press, p. 12, 1998.

JONES, M. G.; JONES, B. D.; HARGROVE, T. Y. The unintended consequences of high-stakes testing. New York: Rowman \& Littlefield, 2003.

KATZ, P. Development of children's racial awareness and intergroup attitudes. In: KATZ, L. G. (Org.). Current topics in early childhood education. Norwood, NJ: Ablex, 1982. v. 4, p. 17-54.

KOHL, H. I won't learn from you: and other thoughts on creative maladjustment. New York: New Press, 1994.

KOZOL, J. Savage inequalities. New York: Crown, 1991.

LANE, C. (Org.). The psychoanalysis of race. New York: Columbia University Press, 1998.

LIPMAN, P. High stakes education: inequality, globalization, and urban school reform. New York: RoutledgeFalmer, 2004. 
MACEDO, D. The colonialism of the English Only movement.

Educational Researcher. v. 29, n. 3, 2000. p. 15-24.

MCCARTHY, C. Race and curriculum. London: Falmer Press, 1990.

. Rethinking liberal and radical perspectives on racial inequality in schooling: Making the case for non-synchrony. Harvard Educational Review, v. 58, n. 3, p. 265-279, 1988.

. After the canon: knowledge and ideological representation in the multicultural discourse on curriculum reform. In: MCCARTHY, C.; CRICHLOW W. (Org). Race, identity and representation in education. New York: Routledge, 1993. p. 289-305.

MCCARTHY, C.; CRICHLOW, W. (Org.). Race, identity and representation in education. New York: Routledge, 1993.

MCDERMOTT, R. P. Achieving school failure. In: SPINDLER, G. (Org.). Education and cultural process: toward an anthropology of education. New York: Holt, Rinehart \& Winston, 1974. p. 82-118.

MCNEIL, L. M. Contradictions of school reform: educational costs of standardized testing. New York: Routledge, 2000.

MILES, R. Racism. London: Routledge, 1989. . Racism after 'race relations'. London: Routledge, 1993.

MORRISON, T. Playing in the dark: whiteness and the literary imagination. Cambridge: Harvard University Press, 1992.

MOSES, M. S. Embracing race: why we need race-conscious education policy. New York: Teachers College Press, 2002.

NIETO, S. The light in their eyes: creating multicultural learning communities. New York: Teachers College Press, 1999.

. Affirming diversity: the sociopolitical context of

multicultural education. New York: Longman, 2004.

OAKES, J. Keeping track: how schools structure inequality. New Haven: Yale University Press, 1985.

OMI, M.; WINANT, H. Racial formation in the United States. 2. ed. New York: Routledge, 1994.

ORFIELD, G.; KORNHABER, M. L. (Org.). Raising standards of raising barriers? Inequality and high-stakes testing in public education. New York: The Century Foundation Press, 2001. 
PALEY, V. G. White teacher. Cambridge: Harvard University Press, 1979/1989.

PHINNEY, J.; ROTHERMAN, M. (Org.). Children's ethnic socialization: pluralism and development. Beverly Hills, CA: Sage Publications, 1987.

RAMSEY, P. G. Growing up with the contradictions of race and class. Young Children, v. 50, n. 6, p. 18-22, 1995.

ROOT, M. P. P. (Org.). The multiracial experience: racial borders as the new frontier. Thousand Oaks, CA: Sage Publications, 1996.

ROMAN, L. G. White is a color! White defensiveness, postmodernism and anti-racist pedagogy. In: MCCARTHY, C.; CRICHLOW, W. (Org.). Race, identity and representation in education. New York: Routledge, 1993. p. 71-88.

ROSEBERRY, W. Multiculturalism and the challenge of anthropology. Social Research, v. 59, n. 4, p. 841-858, 1992.

SALOMON, L. R. Roots of justice: stories of organizing in communities of color. San Francisco: Jossey-Bass, 1998.

SCHNEIDER, B. (Org,). Race: An anthology in the first person. New York: Crown, 1997.

SCHNIEDEWIND, N.; DAVIDSON, E. Open minds to equality: a sourcebook of learning activities to affirm diversity and promote equity. 2. ed. Boston: Allyn and Bacon, 1998.

SHANNON, P. The struggle to continue: progressive reading instruction in the United States. Portsmouth, NH: Heinemann, 1990. . Reading poverty. Portsmouth, NH: Heinemann, 1998.

SLEETER, C. E. Empowerment through multicultural education. Albany, NY: State University of New York Press, 1991.

. How white teachers construct race. In: MCCARTHY, C.; CRICHLOW, W. (Org.). Race, identity and representation in education. New York: Routledge, 1993. p. 157-171. White silence, white solidarity. In: IGNATIEV, N.; GARVEY, J. (Org.). Race traitor. New York: Routledge, 1996. p. 257-265.

SLEETER, C. E.; GRANT, C. A. An analysis of multicultural education in the United States. Harvard Educational Review, v. 57, n. 4, p. 421-443, 1987. 
SLEETER, C. E.; MCLAREN, P. L. (Org.). Multicultural education, critical pedagogy and the politics of difference. Albany, NY: State University of New York Press, 1995.

STEELE, S. The content of our character. New York: HarperCollins, 1990.

TATUM, B. D. Teaching white students about racism: The search for white allies and the restoration of hope. Teachers College Record, v. 95, n. 4, p. 462-476, 1994.

Why are all the Black kids sitting together in the cafeteria? New York: Basic Books, 1997.

TAYLOR, C. Multiculturalism and the politics of recognition. Princeton, NJ: Princeton University Press, 1992.

TERKEL, S. Race: how Blacks and Whites think and feel about the American obsession. New York: Free Press, 1992.

THOMPSON, B.; SANGEETA, T. (Org.). Names we call home: autobiography on racial identity. New York: Routledge, 1996.

TROYNA, B.; HATCHER, R. Racism in children's lives. London: Routledge, 1992.

WALLACE, K. Relative/Outsider: the art and politics of identity among mixed heritage students. Westport, CN: Ablex Publishing, 2001.

WALZER, M. Multiculturalism and the politics of interest. In: BIALE, D.; GALCHINSKY, M.; HESCHEL, S. (Org.). Insider/Outsider: American Jews and multiculturalism. Berkeley: University of California Press, 1998. p. 88-98.

WATERS, M. Ethnic options: choosing identities in America. Berkeley: University of California Press, 1990.

WEIS, L.; FINE, M. (Org.). Construction sites: excavating race, class, and gender among urban youth. New York: Teachers College Press, 2000.

WELLMAN, D. Portraits of white racism. 2. ed. New York: Cambridge University Press, 1993.

WEST, C. Race matters. Boston: Beacon Press, 1993.

WETHERELL, M.; POTTER, J. Mapping the language of racism. New York: Columbia University Press, 1992. 
WILSON, W. J. The truly disadvantaged: the inner city, the underclass, and public policy. Chicago: University of Chicago Press. 1987.

WILLETT, C. (Org.). Theorizing multiculturalism: a guide to the current debate. Oxford: Blackwell Publishers, 1998.

WINANT, H. Racial conditions. Minneapolis: University of Minnesota Press, 1994.

WRAY, M.; NEWITZ, A. (Org.). White trash: race and class in America. New York: Routledge, 1997.

YEO, F. L. Inner-city schools, multiculturalism and teacher education. New York: Garland Publishing, 1997.

ZACK, N. Race and mixed race. Philadelphia: Temple University Press, 1993.

(Org.). Race/Sex: their sameness, difference, and interplay. New York: Routledge,1997.

Ronald David Glass, Ph.D., professor associado de Filosofia da Educação na Universidade da Califórnia, Santa Cruz, é diretor do Centro de Pesquisa Colaborativa para uma Califórnia Igualitária (http://ccrec.ucsc.edu) e também atua como diretor associado da Iniciativa de Informação e Democracia do Centro de Pesquisa sobre Tecnologia de Informação para a Sociedade. Realiza pesquisas sobre questões morais e políticas nos processos de aprendizagens públicas para a formação de sociedades justas e democráticas.

rglass@ucsc.edu

Recebido em 25 de abril de 2011.

Aprovado em 18 de abril de 2012. 
